\title{
Treatment of wastewater from a slaughterhouse by gliding arc humid air plasma: Chlorophyll degradation
}

\author{
Jourdin Gongwala ${ }^{1,2, ~ *, ~ S e r g e ~ A l a i n ~ D j e p a n g ~}{ }^{2,3}$, Paltahe Abba ${ }^{1,2}$, Gaston Payom², \\ Samuel Laminsi ${ }^{2}$, Daniel Njopwouo ${ }^{2}$ \\ ${ }^{1}$ Department of Chemistry, Higher Teachers' Training College, University of Maroua, P. O. Box. 55 Maroua, Cameroon \\ ${ }^{2}$ Department of Inorganic Chemistry, Faculty of Science, University of Yaoundé I, P. O. Box. 812 Yaoundé, Cameroon \\ ${ }^{3}$ Institute of Geological and Mining Research, P.O. Box. 4110 Yaoundé, Cameroon
}

\section{Email address:}

gongwala@yahoo.fr (J. Gongwala), sdjepang@yahoo.fr (S. A. Djepang), abbapaltahe@yahoo.fr (P. Abba), gn_payom@yahoo.fr (G. Payom), s.laminsi@yahoo.fr(S. Laminsi), dnjop@yahoo.fr (D. Njopwouo)

\section{To cite this article:}

Jourdin Gongwala, Serge Alain Djepang, Paltahe Abba, Gaston Payom, Samuel Laminsi, Daniel Njopwouo. Treatment of Wastewater from a Slaughterhouse by Gliding Arc Humid Air Plasma: Chlorophyll Degradation. International Journal of Environmental Protection and Policy. Vol. 2, No. 3, 2014, pp. 118-125. doi: 10.11648/j.ijepp.20140203.13

\begin{abstract}
Wastewater samples from liquid effluents of a slaughterhouse in the city of Yaounde (Cameroon) was first analyzed and exposed to gliding arc (glidarc) electric discharge to reduce the pollution load. The analyzed results showed high levels of organic pollution parameters $\left(\mathrm{BOD}_{5}=2000 \mathrm{mg} / \mathrm{L}, \mathrm{COD}=30544 \mathrm{mg} / \mathrm{L}\right)$ and the presence of a large amount of microorganisms. The UV-Visible spectrum showed an absorbance peak at $663 \mathrm{~nm}$ which can be attributed to chlorophyll. A hexane extract of green leaves of senna alata was thus exposed to the plasma to follow the degradation of chlorophyll. After 30 minutes of treatment, reduction rates of $96 \%$ and $73 \%$ respectively were obtained for $\mathrm{BOD}_{5}$ and COD. The absorption peak disappears and a discoloration rate of $76 \%$ was obtained. Microorganisms such as fecal coliforms and fecal streptococci present in large quantities were completely destroyed by plasma after 15 minutes of exposure to the electric discharge. In addition, the decrease in total organic carbon showed that there was mineralization of chlorophyll contained in senna alata. This study shows that the gliding arc plasma is effective in cleaning the wastewater from slaughterhouses and in degrading chlorophyll.
\end{abstract}

Keywords: Gliding arc plasma, Wastewater, Slaughterhouse, Pollution, Chlorophyll, Degradation

\section{Introduction}

Contamination of water resources, especially in terms of quality, is a problem that is particularly acute today. It is the result of the massive use of organic and mineral pollutants from agricultural, urban and industrial sources. These pollutants are released into water sources thereby contaminating them. They have adverse and varied effects on the environment: water-borne diseases, eutrophication of waterways, etc. [1]. Slaughterhouses are among the structures that pollute the environment [2-4]. Apart from the blood, horns, hair, hooves that are released after slaughtering, it is observed that, enormous quantities of solid waste from the paunch and intestines invade nearby rivers. These wastes are sometimes and partly driven by the waters of carcass cleaning and tripe washing or simply accumulated nearby slaughterhouses. Thus, water sources and other surfaces that receive these emissions are highly colored. If the red color observed originates from blood [3], the green color is certainly due to the chlorophyll in plant species that slaughtered animals naturally consume [5]. Faced with this situation, we must therefore undertake concrete actions for the prevention, reduction and even elimination of pollution from this activity of slaughtering animals. Classical waste removal processes such as biodegradation and flocculation with iron salts are currently used, but they have become inadequate nowadays with respect to the more drastic imposed environmental regulations [6,7]. Therefore, it is necessary to find an effective method of wastewater treatment capable of removing color and degrading toxic and harmful substances from effluents. Looking for new depollution techniques, we considered the electric discharge as a green source of reactive species able to abate pollution of wastewater and degrade pollutant molecules: one of the most promising and efficient device is potentially the gliding 
arc technique. The glidarc discharge belongs to the group of non thermal plasmas, although it is formed from an electric arc. It is actually a quenched plasma operated at atmospheric pressure $[8,9]$. The energy transfer from the electric field to the ambient gas leads to the formation of activated species. The nature of these species depends on the type of gas used: for the humid air plasmas, they are derive from $\mathrm{N}_{2}, \mathrm{O}_{2}$, and $\mathrm{H}_{2} \mathrm{O}$ (Fig. 1) and therefore hydrogen peroxide, ozone or nitrogen oxides are expected, although $\mathrm{O}_{3}$ is not favored by the occurrence of water vapor and the high temperature of the gas [10-13]. Emission spectroscopy investigation measurements showed the formation of $\mathrm{HO}^{\circ}$ and $\mathrm{NO}^{\circ}$ radicals in the arc and in the plasma plume of the gliding discharge [14-23]. These species are the main active reagents formed with derivative species such as peroxynitrite or the matching acid formed from their reaction with the parent molecules [24]. Fig. 1 shows that the oxidizing properties of the discharge are mainly due to $\mathrm{OH}$ radicals, while the $\mathrm{NO}^{\bullet}$ radicals are considered as parent molecules for acid derivatives and the complex formation reaction of $\mathrm{H}_{2} \mathrm{O}_{2}$ with $\mathrm{Ti}(\mathrm{IV})$ and $\mathrm{V}(\mathrm{V})$ ions [25]. Peroxynitrous acid $\mathrm{ONOOH}$ is an excellent vector to get $\mathrm{HO}^{\circ}$ and $\mathrm{NO}_{2}{ }^{\circ}$ in the liquid phase where homolysis reaction takes place. The resulting plasma-chemical treatment on aqueous solutions thus induces acid effects which are due to transient $\mathrm{HNO}_{2}$ and $\mathrm{ONOOH}$ (medium or weak acids) and stable $\mathrm{HNO}_{3}$ (strong acid) [26]. In addition, oxidizing effects related to the strong oxidizing properties of $\mathrm{OH}^{\circ}, \mathrm{H}_{2} \mathrm{O}_{2}$, $\mathrm{ONOOH}$ and $\mathrm{ONOO}^{-}$: $\left[\mathrm{E}^{\circ}\left(\mathrm{OH}^{*} / \mathrm{H}_{2} \mathrm{O}_{2}\right)=2.85 \mathrm{~V} / \mathrm{SHE}\right.$; $\mathrm{E}^{\circ}\left(\mathrm{H}_{2} \mathrm{O}_{2} / \mathrm{H}_{2} \mathrm{O}\right)=1.68 \mathrm{~V} / \mathrm{SHE} ; \mathrm{E}^{\circ}\left(\mathrm{ONOOH} / \mathrm{NO}_{2}\right)=2.05$ $\left.\mathrm{V} / \mathrm{SHE} ; \mathrm{E}^{\circ}\left(\mathrm{ONOO}^{-} / \mathrm{ONOOH}\right)=2.44 \mathrm{~V} / \mathrm{SHE}\right]$ have higher potentials than ozone or oxygen $\left[\mathrm{E}^{\circ}\left(\mathrm{O}_{3} / \mathrm{H}_{2} \mathrm{O}_{\text {liquid }}\right)=1.51\right.$ $\left.\mathrm{V} / \mathrm{SHE} ; \mathrm{E}^{\circ}\left(\mathrm{O}_{2} / \mathrm{H}_{2} \mathrm{O}_{\text {liquid }}\right)=1.23 \mathrm{~V} / \mathrm{SHE}\right]$, because these latter values must be corrected for gas solubility in case of practical application [27]. The objective of this work is to reduce the pollution load of effluents and show that it is possible to degrade the chlorophyll contained in these waters. Indeed, the technique of cold plasma treatment nowadays offers more convenience and benefits over conventional treatment methods that are commonly used, such as membrane filtration, flocculation, coagulation, biological treatment, etc. $[1,28]$.

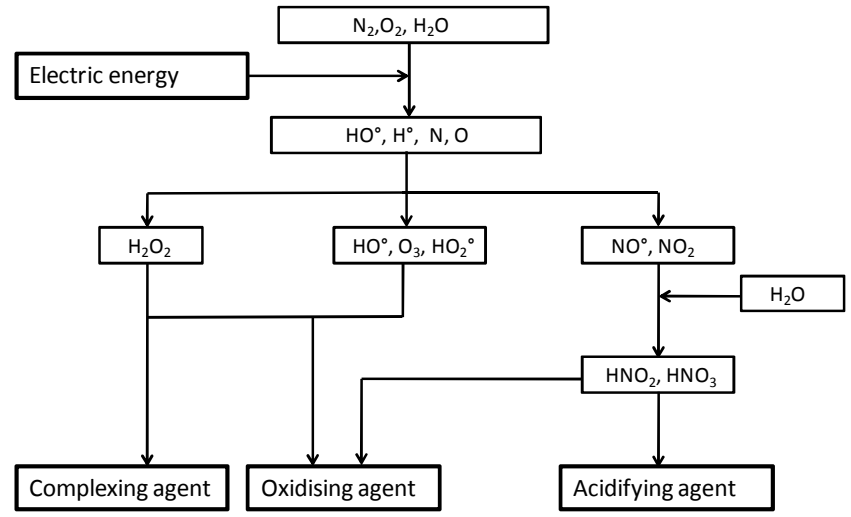

Figure 1. Main molecular species in humid air plasma [27]

\section{Material and Methods}

\subsection{Plasma Glidarc Reactor}

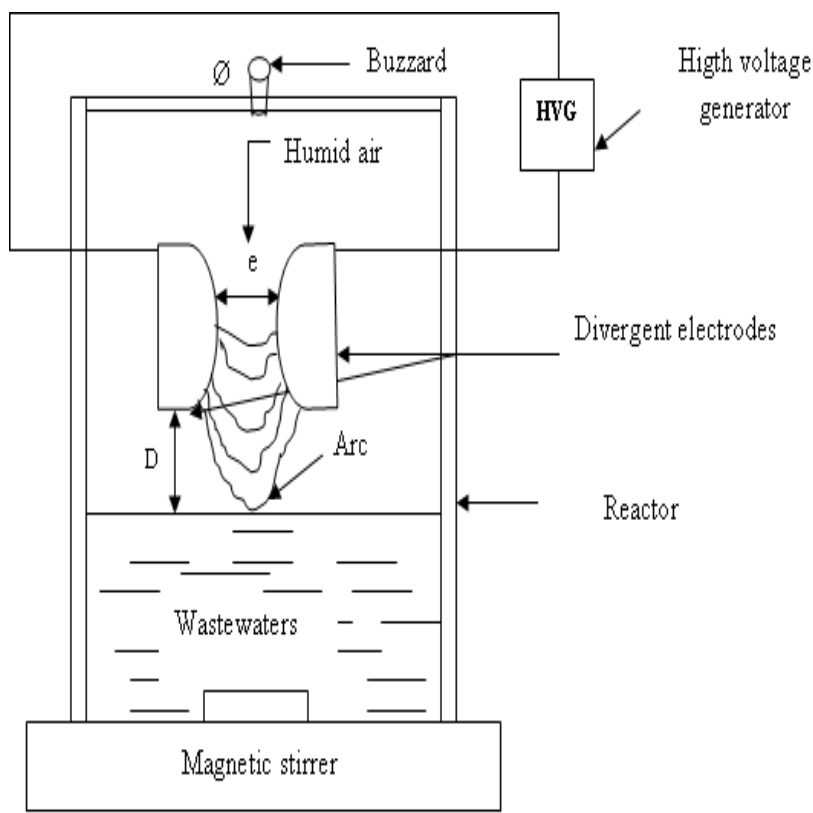

Figure 2. Experimental set-up of the glidarc plama

The plasma device used was proposed by Czernichowski in 1988 under the name of "gliding arc" or "glidarc" and primarily developed for the treatment of gas [8]. Its principle is based on the establishment of an appropriate potential difference of 5-10 kV between two divergent conductors arranged at a short distance (Fig. 2). Power is provided by an electrical transformer (Aupem-Sefli) delivering the output alternating current of $100 \mathrm{~mA}$ and a voltage of $9 \mathrm{kV}$ in open conditions, but the operating current is $160 \mathrm{~mA}$ and voltage is lowered to $0.6 \mathrm{kV}$ [29]. The power used is then of the order of $100 \mathrm{~W}$ which indicates a modest energy cost [3]. Air is directly provided by a compressor and passes through a flowmeter and a bubbling flask filled with distilled water to get water saturated air before being injected in the reactor along the symmetry axis of the two diverging electrodes. The electrodes are symmetrically disposed in the vessel around a buzzard $(\varnothing=1 \mathrm{~mm})$. A discharge occurs at a minimum spacing of the electrodes $(\mathrm{e}=2 \mathrm{~mm})$ and the feet of the arc formed are pushed into the ends of the electrodes by the gas flow directed along the axis of the reactor [28]. Ionized channel arc stretches during its progression, its volume increases and hence its temperature decreases before it explodes into a plume and tempered plasma to be short-circuited by a new arc. A liquid target can then be opposed to the plume and thereby brought into contact with highly reactive species $\left(\mathrm{NO}^{\circ}\right.$ and $\mathrm{HO}^{\circ}$ ) responsive to the target-plasma interface [30-34]. The diffusion process in the liquid is improved by convection in the liquid phase due to the air flow and by a magnetic stirrer. Furthermore, operation at atmospheric pressure of the discharge induces a limited increase of the macroscopic temperature of the target. The pyrex reactor used is double-walled and is provided 
with a cooling system by a simple water circulation, which can limit the rise in temperature during the exposure of the target while maintaining the temperature of the reaction medium to a value not exceeding thirty degrees [35]. The air flow rate is fixed at $800 \mathrm{~L} / \mathrm{h}$ and the distance electrodes-solution $\mathrm{D}$ is $2.5 \mathrm{~cm}$. The other working parameters selected from the plasma batch reactor are constant according to the different results obtained in previous work $[30,36]$.

\subsection{Sampling}

The following observations at the site of wastewater withdrawal from the Etoudi slaughterhouse in Yaoundé oriented operations: activities are ongoing every day throughout the year with the same products; the wastewater discharge is continuous regardless of the seasons and the release rate is slow and continuous through a single discharge channel in the river. Therefore, samples were collected at a single point. All arrangements were made to have a representative and homogeneous samples as indicated by Rodier [1]. The samples were then stored in plastic containers at low temperature $\left(4^{\circ} \mathrm{C}\right)$ before analyses and treatment.

The chlorophyll extract from green leaves of senna alata was done with hexane (100\%). Indeed, the leaves were crushed and soaked in hexane. After stirring, the mixture was filtered and the solvent was recovered by means of a rotary evaporator of Büchi Rotavapor $\square \mathrm{R} \square \mathrm{N}^{\mathrm{o}} 17697$ mark For the preparation of the solution, $1 \mathrm{~mL}$ of the chlorophyll extract was dissolved in 1L of methanol (99\%), and then this solution was spread over a volume of $2 \mathrm{~L}$ using distilled water. Finally, $1 \mathrm{~mL}$ of this extract was dissolved in a water/methanol mixture $(50 / 50)$ before plasma treatment.

\subsection{Analytical Procedures}

Measurements of $\mathrm{pH}$, conductivity and total dissolved solids (TDS) were made by a digital multimeter of HANNA HI 9811-5 pH/ ${ }^{\circ} \mathrm{C} / \mathrm{EC} / \mathrm{TDS}$ mark. Before any measurement, the $\mathrm{pH}$-meter was calibrated using buffer solutions $\left(\mathrm{Na}_{2} \mathrm{HPO}_{4} / \mathrm{H}_{2} \mathrm{NaPO}_{4}, \mathrm{pH}=6.85\right.$ and/or $\mathrm{KHC}_{8} \mathrm{H}_{4} \mathrm{O}_{4}, \mathrm{pH}=$ 4.01).

The determination of total suspended solids (TSS) was done by the "absorptiometer" method. The amount of TSS of each sample was read directly from the spectrophotometer of Hach DR/3900 mark. The turbidity was determined by the same apparatus.

The absorption spectra of the various samples were recorded on a spectrophotometer (HACH DR 3900, 340-900 $\mathrm{nm})$ with digital display, computerized for storage and processing of spectra. It has also been used for the measurement of absorbances at the wavelengths of absorption characteristics of the sample $(663 \mathrm{~nm})$ and that of the solution of the extract of senna alata $(671 \mathrm{~nm})$.

The measurement of the chemical oxygen demand (COD) is given by the method said of "digestion reactor". After homogenization of the samples, $2 \mathrm{~mL}$ are taken and introduced into COD tubes, then incubated in the presence of a witness at $150{ }^{\circ} \mathrm{C}$ for 2 hours in a COD reactor (multitube heater) of Hach mark. The COD value of each sample is read after cooling of the tubes to the spectrophotometer of Hach DR/3900 mark.

The determination of biochemical oxygen demand in five days $\left(\mathrm{BOD}_{5}\right)$ was done by the "manometric" method using a $\mathrm{BOD}_{5}$ device of Hach (model 2173B) mark. BOD 5 bottles containing a given volume of wastewater sample from slaughterhouse to which was added a $\mathrm{BOD}_{5}$ nutrient buffer were incubated for 5 consecutive days at a temperature of $20{ }^{\circ} \mathrm{C}$. During this period, the bacteria use the oxygen present in the upper part of the bottle in order to oxidize the organic matter present in the solution and release the $\mathrm{CO}_{2}$ which is fixed by the crystals of potassium hydroxide (present in the cup located at the head of each cylinder). It follows a depression of the air in the bottle, creating a rise in column of mercury. $\mathrm{BOD}_{5}$ value was read directly on the $\mathrm{BOD}_{5}$ scale situated in forehead of the device.

The total organic carbon (TOC) was analyzed using a Spectroquant ${ }^{\circledR}$ TOC Test Kit (HACH). By mineralization with sulfuric acid and peroxodisulphate, carboned compounds are converted to carbon dioxide which reacts with an indicatory solution whose coloration is determined by colorimetry. A volume of sample was previously prepared in a beaker and then pipetted using a micropipette placed in a TOC tube (measurement range: $0-1500.0 \mathrm{mg} / \mathrm{L}$ of TOC); this tube was then heated to $120{ }^{\circ} \mathrm{C}$ for 2 hours with the thermoreactor. Coloration formed was measured with a $\mathrm{HACH} \mathrm{DR} / 890$ colorimeter that gives directly the value of TOC.

The fecal streptococci (FS) and fecal coliforms (FC) present in the water were determined by the membrane filter technique and counted according to the standard protocol described by Rodier [1]. After decimal dilution of the samples using the sterilized dilution water, the samples were filtered on a membrane using a vacuum pump, and then the filtration membranes placed in the respective environments of culture. These were then placed in incubators at $35^{\circ} \mathrm{C}$ for FS and $44.5^{\circ} \mathrm{C}$ for FC. The incubation time was 24 hours. After incubation, the colonies were enumerated.

\section{Results and Discussion}

\subsection{Characteristics of Raw Samples}

The analyses and treatments focused successively on two types of samples i.e. wastewater from the Etoudi slaughterhouse in Yaoundé (Cameroon) and an extract of green leaves of senna alata. The first type of sample was used to determine the state of water pollution from liquid discharges from the slaughterhouse and consequently their impact on the environment. As for the second type of sample, it was about trying to glimpse the study of plasma glidarc degradation of chlorophyll contained in the green leaves of plants that are mostly consumed by animals slaughtered in slaughterhouses [5]. 
The analysis of wastewater from the Etoudi slaughterhouse shows that they are slightly basic $(\mathrm{pH}=7.9)$; conductive $(3000 \mu \mathrm{S} / \mathrm{cm})$ and polluted as the organic parameters $\left(\mathrm{COD}, \mathrm{BOD}_{5}\right)$, the biological parameters (fecal coliforms and fecal streptococci) and the physicochemical parameters (total suspended solids and turbidity) shown in Table 1 attest it. Most of the values are beyond the Cameroonian Standards. The UV-Visible spectrum shows an absorbance peak between 630 and $740 \mathrm{~nm}$ characteristic of the presence of chlorophyll in the samples which is likely to $663 \mathrm{~nm}$ (Fig. 3). Moreover, the follow-up of these parameters after treatment during different exposure times $t^{*}$ of the samples to the glidarc plasma permits the appreciation of the reduction of the pollution in acidic and natural media.

\subsection{Characteristics of the Samples Treated with Plasma Glidarc}

\subsection{1. pH and Buffering}

The medium seems to be buffered because of the small changes in $\mathrm{pH}$ values of the wastewater from the slaughterhouse. Fig. 4 shows that the $\mathrm{pH}$ decreases very slightly even when the medium is acidified. This result is consistent with those of the work of Moussa et al. [33] on acid properties of plasma and those of Gnokam-Zumgang [3] who exposed to discharge a solution of hemoglobin and blood from liquid waste from a slaughterhouse. After 30 minutes of treatment a reduction of around $0.4 \mathrm{pH}$ unit was observed. On the other hand for the extract of senna alata, the $\mathrm{pH}$ drops significantly from the first moments of treatment and slightly between 5 and 20 minutes before reaching a pseudo-equilibrium beyond 20 minutes of treatment.

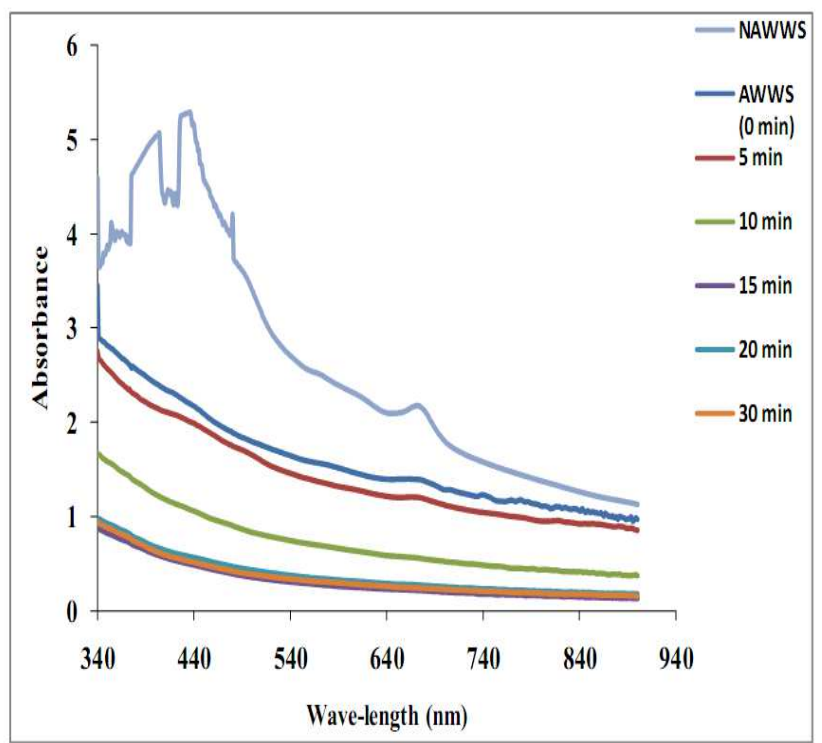

Figure 3. UV-Visible spectrum of acidified slaughterhouse wastewater sample at different exposure times $t^{*}$ (min) [NAWWS: Non-acidified wastewater sample; AWWS: Acidified wastewater sample]

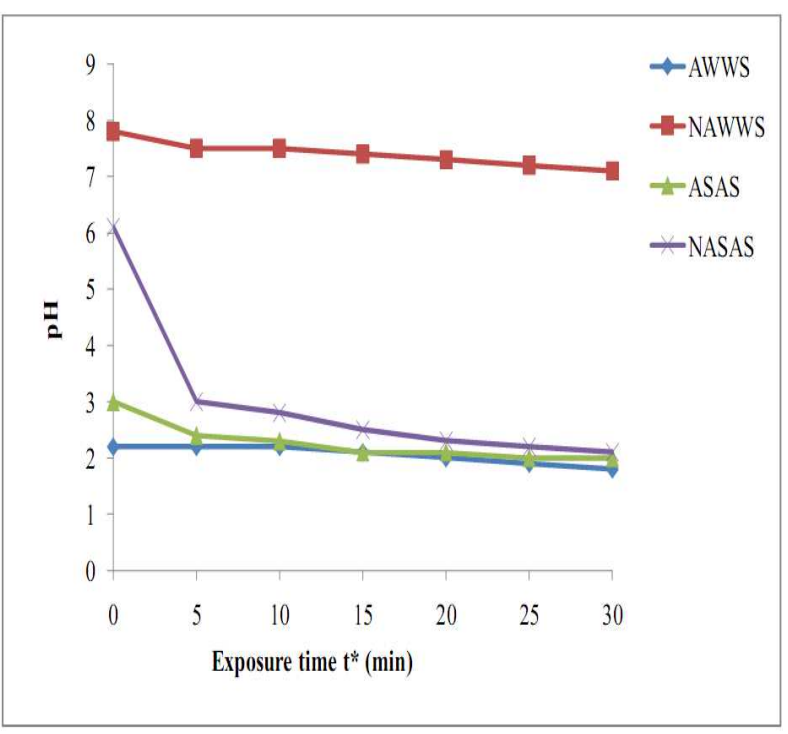

Figure 4. Evolution of pH as a function of exposure time $t^{*}$ (min) [AWWS: Acidified wastewater sample; NAWWS: Non-acidified wastewater sample; ASAS: Acidified senna alata sample; NASAS: Non-acidified senna alata sample]

\subsubsection{Conductivity and Total Dissolved Solids}

The conductivity measurement shows that there's a significant mineralization of the different samples exposed to discharge (Table 2). The concentration of the mineral species in solution increases with exposure time to the glidarc plasma. As for the total dissolved solids (TDS), their curve has the same shape as that of the conductivity showing that there's an increase of the ionic species in solution during treatment. An increase in conductivity with time of treatment was also demonstrated in the study of the degradation of organic compounds in aqueous solution by glidarc plasma [14], in the treatment of wastewater discharges from a brewery and even in the exposure of distilled water to glidarc plasma $[31,36]$.

\subsubsection{Turbidity and Total Suspended Solids}

Total suspended solids (TSS) decreased rapidly after $t^{*}=$ 30 min of exposure time to glidarc plasma reaching a value of $84 \mathrm{mg} / \mathrm{L}$, which corresponds to a reduction rate of $68 \%$. Turbidity also decreases rapidly after 5 minutes of exposure to the discharge and then weakly as indicated by the values obtained from 5 to $30 \mathrm{~min}$ (Table 3 ).

\subsubsection{Chemical and Biochemical Oxygen Demand}

The effluent is heavily loaded with organic matter as evidenced by measurements of COD and $\mathrm{BOD}_{5}$ (Table 1). The values are very high, but during treatment there was a marked decrease of $\mathrm{COD}$ and $\mathrm{BOD}_{5}$ after 30 minutes of exposure to glidarc plasma reaching respectively $73 \%$ and 96\% abatement rate (Fig. 5). These high levels of organic materials have also been obtained by Bai et al. [37] concerning urban wastewater in India and also by Gongwala et al. [2] with the wastewater from another slaughterhouse in Yaounde (Cameroon). The plateau obtained between 20 and $30 \mathrm{~min}$ on the COD curve can be due to the fact that the 
organic load has become weak, which is a reminder of the impact of glidarc on dilute solutions. The rate of reduction of COD confirms the effectiveness of plasma process to reduce the pollutant load contained in the wastewater.

Table 1. Results of analyses on collected wastewater sample [CS: Cameroonian Standards; TDS: Total dissolved solids; TSS: Total suspended solids; COD: Chemical oxygen demand; $B O D_{5}$ : Biochemical oxygen demand in five (5) days; FC: Fecal coliforms; FS: Fecal streptococci]

\begin{tabular}{cccc}
\hline Parameters & Units & Value & CS \\
\hline $\mathrm{pH}$ & & 7.8 & $6-9$ \\
Conductivity & $\mu \mathrm{S} / \mathrm{cm}$ & 2920 & \\
TDS & $\mathrm{mg} / \mathrm{L}$ & 1480 & 1000 \\
Turbidity & $\mathrm{Pt} / \mathrm{Co}$ & 3643 & \\
$\mathrm{TSS}$ & $\mathrm{mg} / \mathrm{L}$ & 260 & 50 \\
$\mathrm{COD}$ & $\mathrm{mg} / \mathrm{L}$ & 30544 & 250 \\
$\mathrm{BOD}$ & $\mathrm{mg} / \mathrm{L}$ & 2000 & 50 \\
$\mathrm{FC}$ & $\mathrm{UFC}$ & 120000 & 2000 \\
$\mathrm{FS}$ & $\mathrm{UFC}$ & 80000 & 1000 \\
\hline
\end{tabular}

Abdelmalek used the same method for processing samples from rejection of an Algerian textile industry and obtained after $120 \mathrm{~min}$ of treatment a reduction of $71 \%$ under the following conditions: $\mathrm{V}=200 \mathrm{~mL}, \mathrm{Q}=900 \mathrm{~L} / \mathrm{h}$ [7]. The abatements of $\mathrm{BOD}_{5}$ obtained correspond to a reduction in organic matter content due to the formation by the discharge of oxidizing species such as $\mathrm{NO}^{\circ}$ and $\mathrm{HO}^{\circ}$ and their derivatives in aqueous solution. Doubla et al. [31] obtained an abatement rate of $74 \%$ after 30 min of exposure to the discharge of a sample from a Cameroonian food industry waste. Furthermore, the work of Njoyim-Tamungang et al. [32] permitted to show that the reduction in $\mathrm{BOD}_{5}$ depends on the type of emission. It is important to note that the remarkable presence of microorganisms namely fecal coliforms and fecal streptococci (Fig. 6) is a factor contributing to the increase of the measurement of these organic parameters.

Table 2. Results of total dissolved solids (TDS) and conductivity of exposed samples to glidarc plasma [AWWS: Acidified wastewater sample; NAWWS: Non-acidified wastewater sample; ASAS: Acidified senna alata sample; NASAS: Non-acidified senna alata sample]

\begin{tabular}{|c|c|c|c|c|c|c|c|c|}
\hline \multicolumn{2}{|c|}{$\begin{array}{c}\text { Exposure time } t^{*} \\
(\min )\end{array}$} & 0 & 5 & 10 & 15 & 20 & 25 & 30 \\
\hline \multirow[b]{2}{*}{ AWWS } & TDS $(\mathrm{mg} / \mathrm{L})$ & 7750 & 8000 & 8110 & 8130 & 8470 & 9720 & 11460 \\
\hline & $\begin{array}{l}\text { Conductivity } \\
(\mu \mathrm{S} / \mathrm{cm})\end{array}$ & 3940 & 3940 & 4030 & 4050 & 4200 & 4810 & 5730 \\
\hline \multirow[b]{2}{*}{ NAWWS } & TDS (mg/L) & 1480 & 1500 & 1540 & 1550 & 1570 & 1580 & 1590 \\
\hline & $\begin{array}{l}\text { Conductivity } \\
(\mu \mathrm{S} / \mathrm{cm})\end{array}$ & 2920 & 3000 & 3080 & 3110 & 3150 & 3170 & 3190 \\
\hline \multirow[b]{2}{*}{ ASAS } & TDS (mg/L) & 70 & 240 & 460 & 610 & 860 & 980 & 1030 \\
\hline & $\begin{array}{l}\text { Conductivity } \\
(\mu \mathrm{S} / \mathrm{cm})\end{array}$ & 150 & 490 & 920 & 1230 & 1720 & 1970 & 2080 \\
\hline \multirow[b]{2}{*}{ NASAS } & TDS (mg/L) & 0 & 170 & 250 & 520 & 760 & 870 & 1010 \\
\hline & $\begin{array}{l}\text { Conductivity } \\
(\mu \mathrm{S} / \mathrm{cm})\end{array}$ & 0 & 350 & 510 & 1040 & 1430 & 1750 & 2010 \\
\hline
\end{tabular}

Table 3. Abatement and variation of suspended matters (SM) and turbidity of non-acidified wastewater sample with exposure time $t^{*}$ (min) [TSS: Total suspended solids]

\begin{tabular}{clccccccc}
\hline \multicolumn{2}{c}{$\begin{array}{c}\text { Exposure time t* } \\
\text { (min) }\end{array}$} & $\mathbf{0}$ & $\mathbf{5}$ & $\mathbf{1 0}$ & $\mathbf{1 5}$ & $\mathbf{2 0}$ & $\mathbf{2 5}$ & $\mathbf{3 0}$ \\
\hline \multirow{2}{*}{ Turbidity } & $\begin{array}{l}\text { Value } \\
(\mathrm{Pt} / \mathrm{Co})\end{array}$ & 3643 & 665 & 647 & 620 & 615 & 583 & 564 \\
& $\begin{array}{l}\text { Percentage } \\
(\%)\end{array}$ & 0 & 81.75 & 82.24 & 82.98 & 83.12 & 84.00 & 84.52 \\
& $\begin{array}{l}\text { Value } \\
(\mathrm{mg} / \mathrm{L})\end{array}$ & 260 & 156 & 148 & 96 & 92 & 88 & 84 \\
\multirow{2}{*}{$\mathrm{TSS}$} & $\begin{array}{l}\text { Percentage } \\
(\%)\end{array}$ & 0 & 40.00 & 43.08 & 63.08 & 64.62 & 66.15 & 67.69 \\
\hline
\end{tabular}

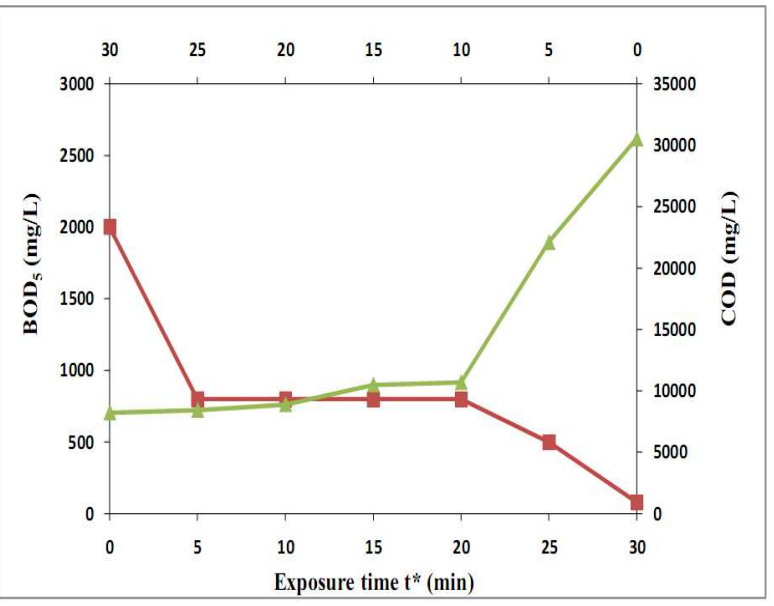

Figure 5. Evolution of $\mathrm{COD}$ and $\mathrm{BOD}_{5}$ as a function of exposure time $t^{*}$ (min)

The works of Nafarnda et al. on the wastewaters from the slaughterhouses in Nigeria present an elevated bacterial population also [38]. Exposure to the discharge of wastewater sample shows that these microorganisms, vectors of many waterborne diseases are completely destroyed after 15 minutes of treatment. These results are consistent with the plasmachemical destruction of the bacteria that have been the subject of several studies in both thermal and non-thermal plasmas [39-41].

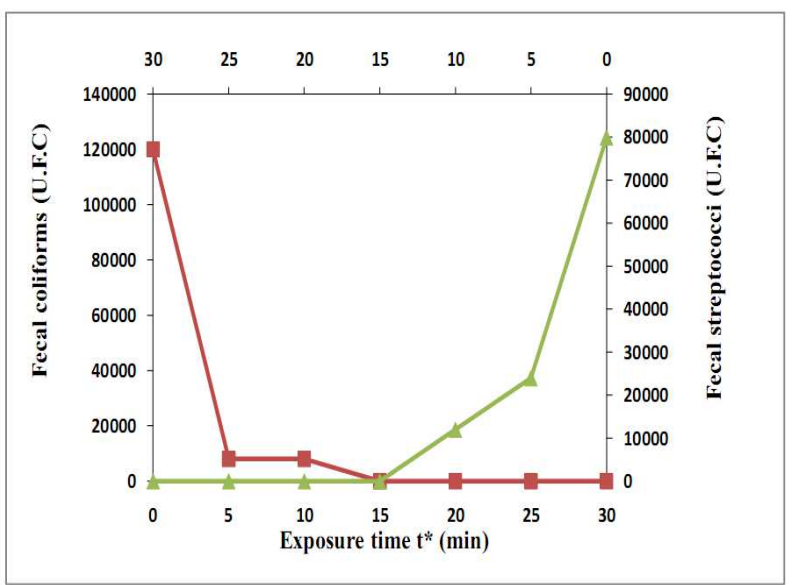

Figure 6. Evolution of fecal populations as a function of exposure time $t^{*}$ (min) 


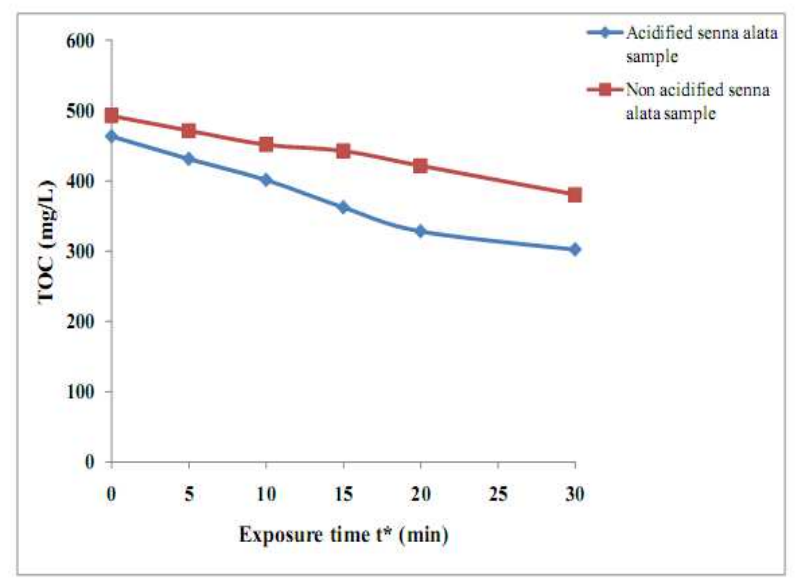

Figure 7. Evolution of TOC as a function of exposure time $t^{*}$ (min)

\subsubsection{Total Organic Carbon}

The decrease in total organic carbon (TOC) observed in Fig. 7 shows once more that the chlorophyll in the wastewater from slaughterhouses can be destroyed by glidarc plasma. This compound in solution is weakly mineralized when the medium is not acidified, but mineralization rate increases after exposure to the discharge of the acidified sample. During treatment, the TOC varies from an initial value of $492 \mathrm{mg} / \mathrm{L}$ to $380 \mathrm{mg} / \mathrm{L}$ after 30 minutes of treatment, giving a mineralization rate of $23 \%$ for the non-acidified sample.

On the other hand, at the end of the same exposure time $\left(t^{*}=30 \mathrm{~min}\right)$, a mineralization rate of $35 \%$ is obtained when an acidified sample is exposed to the discharge (Fig. 8). These different variations constitute a proof of the phenomenon of decomplexing the complex in an acid medium and mineralization of the chlorophyll contained in senna alata extract and the other organic compounds that may be present there.

\subsubsection{Spectrophotometric Analysis}

The UV-Visible spectrum of the sample wastewater of slaughterhouses shows that by acidification of the medium, the main absorption peak due to chlorophyll disappears completely (Fig. 3). This phenomenon can be attributed to the decomplexation process in acid medium of chlorophyll, complex mainly present in the sample considering the wavelength at which the main peak, although having a low intensity is observed. Thereafter the curves decrease gradually as the treatment time increases until it reaches a certain equilibrium which starts at 15 minutes. The Fig. 9 confirms the complete disappearance of the signal between 660 and $680 \mathrm{~nm}$ observed after 30 minutes treatment of an acidified solution of senna alata extract. On the other hand, the non-acidified samples of senna alata present superposable peaks that decrease with the duration of treatment, but do not disappear completely (Fig. 10). We can therefore conclude that the observed decomplexation by prior acidification of the medium contributes to a more effective destruction of chlorophyll contained in senna alata.

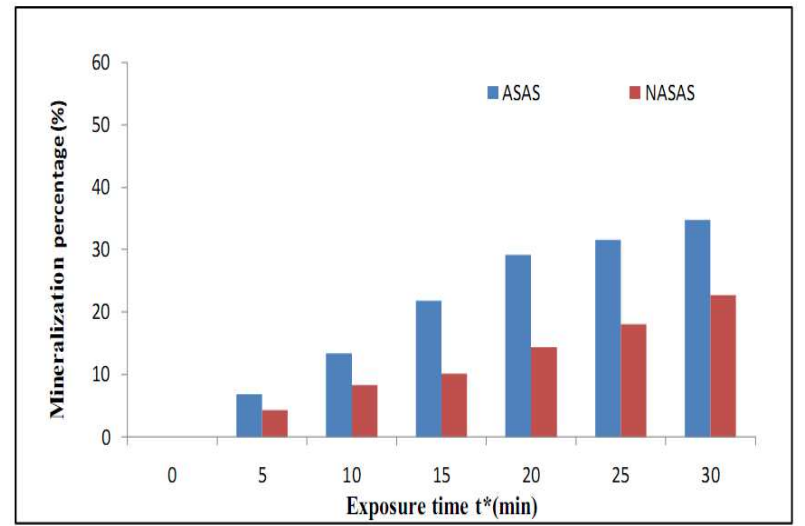

Figure 8. Mineralization percentage (TOC abatement) of senna alata with exposure time $t^{*}$ (min) [ASAS: Acidified senna alata sample; NASAS: Non-acidified senna alata sample]

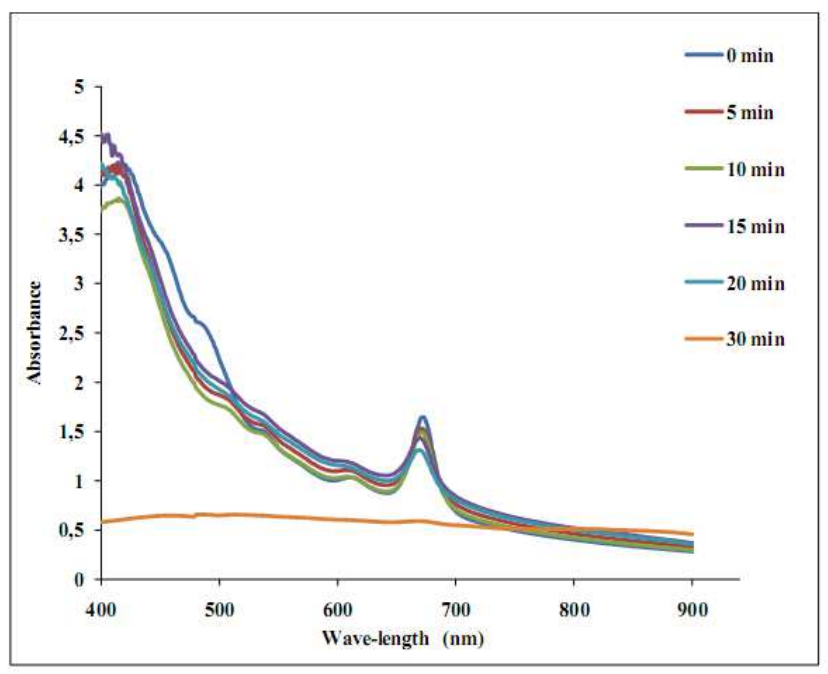

Figure 9. UV-Visible spectrum of acidified senna alata sample at different exposure time $t^{*}$ ( $\left.\mathrm{min}\right)$

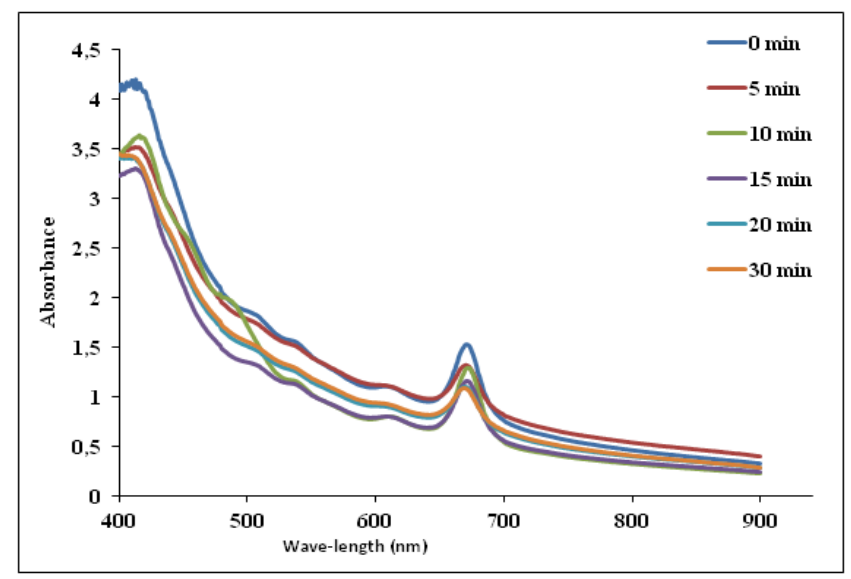

Figure 10. UV-Visible spectrum of non-acidified senna alata sample at different exposure time $t^{*}$ (min)

The absorbance at $663 \mathrm{~nm}$ of the wastewater sample which is proportional to the concentration of chlorophyll according to Dugar Deshna and Bafna [42], decreases progressively with exposure time $t^{*}$ (Fig. 11) regardless of 
the medium ( acid or not). Percentage discoloration was 76\% for the acidified sample and $74 \%$ for the non-acidified at $t^{*}=$ 30 min. Similarly, we observed a slight decrease in absorbance with extract of senna alata and the respective rates of discoloration of $15 \%$ (acid) and 14\% (non-acid) were obtained after 20 minutes of treatment. Let's note however that, at the end of that time $(\mathrm{t} *=20 \mathrm{~min}) \mathrm{a}$ pseudo-equilibrium settles truly reflecting depletion of reactive species associated with a high consumption of these species in the oxidation process of the different samples .

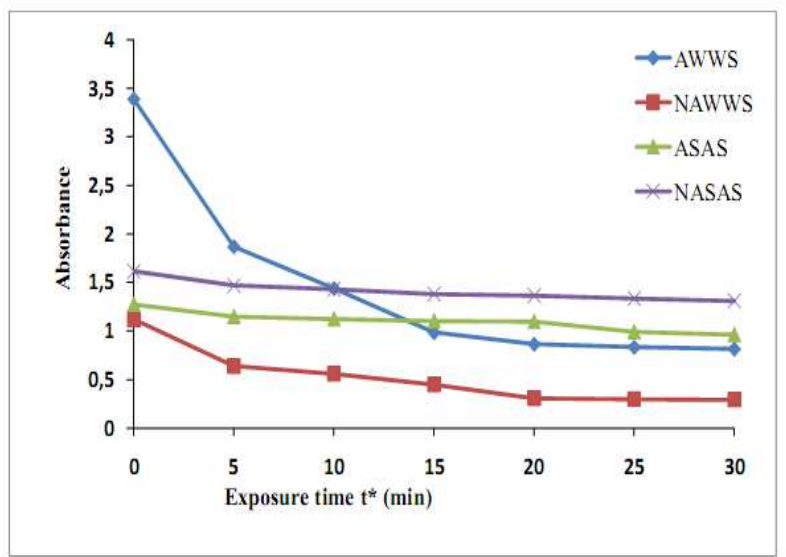

Figure 11. Evolution of absorbance as a function of exposure time $t^{*}$ (min) [AWWS: Acidified wastewater sample; NAWWS: Non-acidified wastewater sample; ASAS: Acidified senna alata sample; NASAS: Non-acidified senna alata sample]

\section{Conclusion}

On the whole, the wastewater from the Etoudi slaughterhouse is heavily loaded with organic matter and microorganisms. Glidarc plasma treatment reduces the pollutant load. $73 \%$ and $96 \%$ abatement rate respectively for $\mathrm{COD}$ and $\mathrm{BOD}_{5}$ are obtained after 30 min of exposure time to the discharge. Percentage discoloration was $76 \%$ for the acidified sample and $74 \%$ for the non-acidified one at the same exposure time. A decrease of absorbance measured around $663 \mathrm{~nm}$ was also observed. These results are the proof that the main molecule responsible for the greenish color of the slaughterhouse effluent namely chlorophyll can be degraded by the process. Thus the problem of nuisance related to the coloration impeding the penetration of light can be resolved. Therefore the life of the fauna and aquatic flora is saved through healthy aeration of water body receiving slaughterhouses wastewater.

\section{Acknowledgments}

This work has been achieved thanks to the Laboratory of Mineral Chemistry and the Laboratory of Phyto-Purification, all of the University of Yaounde I (Cameroon). Special thanks to M. Tsamo Cornelius (Higher Teachers' Training College of the University of Maroua, Cameroon) for his language help after reading the manuscript.

\section{References}

[1] J. Rodier, "The analysis of water (in French)," $9^{\text {th }}$ Edition, Dunod, Paris, 2009.

[2] J. Gongwala, P. Abba, G. Payom, D. Njopwouo, "Analysis and treatment by cold plasma of wastewaters from "the Brasseries'slaughterhouse " in Yaounde (in French)", Int. J. Biol. Chem. Sci., Vol. 6, No. 6, 2012, pp. 7059-7068.

[3] F. D. S. Gnokam-Zumgang, A. Doubla, J. L. Brisset, "Temporal post-discharge reactions in plasma-chemical degradation of slaughterhouse effluents," Chemical Engineering Communications, Vol. 98, 2010, pp. 483-493.

[4] H. Labioui, L. Elmoualdi, Y. Benabbou M. Elyachioui M. Ouhssine, "Processing and recycling of waste from slaughterhouses in Morocco," AgroSolutions, Vol. 18, No. 1, 2007, pp. 35-40.

[5] P. Folly, N. Engel, "Chlorophyll b to chlorophyll a conversion precedes Chlorophyll degradation in Hordeum vulgare L.," Journal of Biological Chemistry, Vol. 274, No. 31, 1999, pp. 21811-21816.

[6] A. Doubla, L. Bouba-Bello, M. Fotso, J. L. Brisset, "Plasmachemical decolourisation of bromothymol blue by gliding electric discharge at atmospheric pressure," Dyes and Pigments, Vol. 77, 2008, pp. 118-124.

[7] F. Abdelmalek, S. Gharbia, B. Benstaali, A. Addou , J. L. Brisset, "Plasmachemical degradation of azo dyes by humid air plasma: Yellow Supranol 4 GL, Scarlet Red Nylosan F3 GL and industrial waste," Water Res., Vol. 38, 2004, pp. 2339-2347.

[8] H. A. Lesueur, A. Czernichowski, J. Chapelle, "Device for generating low temperature plasma by formation of gliding electric discharges (in French)," French Patent No. 88, 14932, 1988.

[9] A. A. Fridman, A. Petrousov, J. Chapelle, J.M. Cormier, A. Czernichowski, H. Lesueur, J. Stevefelt, "Physical model of gliding arc discharge (in Frenh)," J. Phys. III, Vol. 4, 1994, pp. 1449-1465.

[10] H. Matzing, "Chemicals kinetics of the gas cleaning by irradiation with electrons," Adv Chem Phys, LXXX : 315, 1994.

[11] R. Peyrous, B. Held, P. Pignolet, "Kinetic simulation of gaseous species created by an electric discharge in humid air," Papers of Technical Meeting on Electric Discharges, Tokyo, ED, vol. 87-63, 1987, pp. 95-109.

[12] J.S. Chang. "The enhanced effect of in-situ ammonium salt aerosols on the combined removal of $\mathrm{SO}_{2}$ and $\mathrm{NO}_{\mathrm{X}}$ from simulated flue gas in pulsed corona enhanced wet electrostatic precipitators," J Aerosol Sci, Vol. 20, No. 8, 1989, pp. $1087-1090$.

[13] J. L. Brisset, "Lightning in a bottle. Electric gliding discharge at atmospheric pressure and environmental applications (in French)," Le Bup, Vol. 912, No. 103, 2009, pp. 257-280.

[14] B. Benstaali, P. Boubert, B.G. Cheron, A. Addou and J. L. Brisset, "Density and rotational temperatures measurements of the $\mathrm{NO}^{\circ}$ and $\mathrm{HO}^{\circ}$ radicals produced by a gliding arc in humid air and their interaction with aqueous solution," Plasma Chem.Plasma Proc., Vol. 22, 2002, pp. 553-571. 
[15] M. Roustan, J. Mallevialle, H. Roques, J. P. Jones, "Mass transfer of ozone to water: a fundamental study," Ozone Sci.Eng. Vol. 2, 1981, pp. 337-344.

[16] X. Tu, L. Yu, J. Yan, K. Cen, B. Cheron, "Dynamic and spectroscopic characteristics of atmospheric gliding arc in gas-liquid two phases flow," Phys Plasmas, Vol. 16, 113506 , 2009.

[17] B. W. DeMore, S. Sander, D. Golden, R. Hampson, M. Kurylo, C. Howard, A. Ravishankara, C. Kolb, "Chemical kinetics and photochemical data for use in stratospheric modelling evaluation," NASA JPL publication, Vol. 11, 1994, pp. $94-26$

[18] P. Bruggeman, T. Verreyken, M. Gonzales, J. L. Walsh, M. G. Kong, C. Leys, D. C. Schramm, "Optical emission spectroscopy as a diagnostic for plasmas in liquids: opportunities and pitfalls," J. Phys. D: Appl. Phys. Vol. 43, $124005,2010$.

[19] R. Ono, T. Oda, "Measurement of hydroxyl radicals by pulsed corona discharge," J. Electrostatics, Vol. 55, 2002, pp. $333-342$

[20] S. Kanazawa, H. Tanaka, A. Kajiwara, T. Okhubo, Y. Nomoto, M. Kocik, J. Mizeraczyk, J. S. Chang, "LIF imaging radicals in DC positive streamer coronas," Thin Solid films, Vol. 515, No. 42, 2007, pp. 66-71.

[21] M. Sahni, W. Finney, B. Locke, "Quantification of hydroxyl radicals produced in aqueous phase pulsed electrical discharge reactors," Ind. Eng. Chem Res., Vol. 45, No. 58, 2006, pp. 19-25.

[22] J. L. Brisset, E. Hnatiuc, "Peroxynitrite a re-examination of the chemical properties of non thermal discharges burning in air over aqueous solutions," Plasma Chem Plasma Process, Vol. 32, 2012, pp. 655-674.

[23] J. L. Brisset, D. Moussa, A. Doubla, E. Hnatiuc, B. Hnatiuc, G. K. Youbi, J. M. Herry, M. Naitali, M. N. Bellon Fontaine, "Chemical Reactivity of Discharge and temporal Post-Discharge in Plasma Treatment of Aqueous Media: Examples of Gliding Discharge Treated Solutions," Ind. Eng. Chem. Res., Vol. 47, 2008, pp. 5761-5781.

[24] J. L. Brisset, B. Benstaali, D. Moussa, J. Fanmoe, E. Njoyim-Tamungang, "Acidity control of plasmachemical oxidation: application to dye removal, urban wastes abatement and microbial inactivation," Plasma source Sci Technol, Vol. 20, 034021, 2011.

[25] E. Hnatiuc, "Electrical Process of measures and treatment of pollutants (in French)," Ed. Tec \& Doc, 2002, pp. 159-295.

[26] A. Doubla, F. Abdelmalek, K. Khélifa, A. Addou, J. L. Brisset, "Post-discharge plasma-chemical oxidation of Iron (II) complexes," Journal of Applied Electrochemistry, Vol. 33, 2003, pp. 73-77.

[27] D. Moussa, J. L. Brisset, "Disposal of spent tributylphosphate by gliding arc plasma," J. Hazard. Mat. Vol B102, 2003, pp. $189-200$

[28] A. Fridman, "Plasma Chemistry," Cambridge University Press, New York, 2008.

[29] B. Held, "Physics of cold plasmas," Ed. Masson, Paris, 1994.

[30] S. A. Djepang, S. Laminsi, I. Djakaou, T. Koyouaili,
"Removal of black Eriochrome T by Glidarc plasma (in French)," Revue des Sciences de l'Eau, Vol. 27, No. 1, 2014, pp. 71-78.

[31] A. Doubla, S. Laminsi, S. Nzali, E. Njoyim-Tamungang, J. Kamsu-Kom, J. L. Brisset, "Organic pollutants abatement and biodecontamination of brewery effluents by a non-thermal quenched plasma at atmospheric pressure," Chemosphere, Vol. 69, 2007, pp. 332-337.

[32] E. Njoyim-Tamungang, P. Ghogomu, S. Laminsi, S. Nzali, A.Doubla, J. L. Brisset, "Coupling Gliding Discharge Treatment and Catalysis by Oyster Shell Powder for Pollution Abatement of Surface Waters," Ind. Eng. Chem. Res., Vol. 48, 2009, pp. 9773-9780.

[33] D. Moussa, F. Abdelmalek, B. Benstaali, A. Addou, E. Hnatiuc, J. L. Brisset, "Acidity control of the gliding arc treatments of aqueous solutions: application to pollutant abatement and biodecontamination," European Physical Journal of Applied Physics, Vol. 29, 2005, pp. 189-199.

[34] F. Abdelmalek, "Plasma Chemistry of Aqueous Solutions: Application to the Degradation of Toxic Compounds (in French)," Ph.D Dissertation, University of Mostaganem, Algeria, 2003.

[35] R. Burlica, M. J. Kirkpatrick, W. C. Finney, R. J. Clark, B. Locke, "Organic dye removal from Aqueous Solution by gliding arc discharges," J. Electrostat., Vol. 62, 2004, pp. 309-321.

[36] P. Abba, J. Gongwala, S. Laminsi, J. L. Brisset, "The Effect of the Humid Air Plasma on the Conductivity of Distilled Water: Contribution of Ions", Int. J. Res. Chem. Environ., Vol.4, No. 1, 2014, pp. 25-30.

[37] S. Bai, S. Srikantaswamy, D. Shivakumar, "Urban Wastewater Characteristic and Its Management in Urban Areas - a Case Study of Mysore City, Karnataka, India," Journal of Water Resource and Protection, Vol. 2, 2010, pp. 717-726.

[38] W. D. Nafarnda, I. E. Ajayi, J. C. Shawulu, M. S. Kawe, G. K. Omeiza, N. A. Sani, O. Z. Tenuche, D. D. Dantong, S. Z. Tags, "Bacteriological quality of abattoir effluents discharged into water bodies in Abuja, Nigeria," International Scholarly research Network, Vol. 2012, 515689, 2012, 5 p.

[39] R. E. J. Sladek, E. Stoffels, "Deactivation of Escherichia coli by the plasma needle," J. Phys. D: Appl. Phys. Vol. 38, 2005, pp. 1716-1721

[40] M. Moreau, M. G. J. Feuilloley, N. Orange, J. L. Brisset, "Lethal effect of the gliding arc discharges on Erwinia spp," $J$. Appl. Microbiol., Vol. 98, 2005, pp.1039-1046.

[41] G. Kamgang-Youbi, J. M. Herry, M. N. Bellon-Fontaine, J. L. Brisset, A. Doubla, M. Natailli, "Evidence of Temporal Postdischarge Decontamination of Bacteria by Gliding Electric Discharges: Application to Hafnia alvei," Applied And Environmental Microbiology, Vol. 73, No. 15, 2007, pp. $4791-4796$

[42] D. Deshna, A. Bafna, "Effect of lead stress on chlorophyll content, malondialdehyde and peroxidase activity in seedlings of mung bean (Vigna radiata)," International Journal of Research in Chemistry and Environment, Vol. 3, No. 3, 2013, pp. 20-25. 